\title{
Early Detection of Hepatocellular Carcinoma on top of Liver Cirrhosis: The Fas Receptor and Ligand System
}

\author{
Olfat Hammam 1, Manal Zahran ${ }^{2}$, Ola Mahmoud ${ }^{2}$, Sohair Aly ${ }^{3}$, Karim Hosny ${ }^{4}$, \\ Amira Helmy ${ }^{5}$, Amgad Anas ${ }^{6}$ \\ 1 Department of Pathology, Theodor Bilharz Research Institute, Cairo, Egypt \\ 2 Department of Hematology, Theodor Bilharz Research Institute, Cairo, Egypt \\ 3 Advanc Dental/Medical institute IPPT,USM, Malysia \& Medicinial Chemistry Department \\ of NRC,Cairo, Egypt \\ 4 Department of Surgery. Faculty of Medicine (Kasr El Aini Hospital), Cairo University, Egypt \\ 5 Department of Electron Microscop (Hematology), Theodor Bilharz Research Institute, Cairo, Egypt \\ 6 Department of Hepatology \& Gasteroenterology, Theodor Bilharz Research Institute, Cairo, Egypt. \\ Address for correspondence : Theodor Bilharz Research Institute, Cairo, Egypt
}

\section{Abstract \\ Background:}

Hepatocyte aberrations, accumulation of chromosomal damage and possibly initiation of hepatic carcinogenesis is thought to be caused by the continued viral replication and the persistent attempt by a less than optimal immune response to eliminate hepatitis $\mathrm{C}$ virus (HCV) infected cells. The identification of the "death factors" including Fas and its Ligand (Fas-L) as a major regulator of both apoptosis and immune function has provided insight into an attractive mechanism of tumor escape from immune clearance.

Aim: To assess the hepatic expression of Fas/Fas-L, the Fas receptor (Fas-R) expression on lymphocyte, and serum soluble Fas (sFas) in an attempt to analyze the role of Fas receptor/ligand system in the multistep process of fibrosis/carcinogenesis and the possible use of the serum marker as possible candidate biomarkers for an early detection of hepatocellular carcinoma (HCC).

\section{Material and Method:}

The current study included 100 samples from cases at Theodor Bilharz Research Institute and Kasr Al Aini Hospital in Egypt. There were 90 cases of chronic hepatitis C (CHC) infection (and negative hepatitis B virus infection). There were 30 cases without liver cirrhosis, 30 cases with liver cirrhosis and 30 cases with HCC. 10 liver biopsies were taken from healthy livers as normal controls. Histopathologic study and immunohistochemistry for detection of hepatic Fas and Fas-L expression were determined for all cases. Electron microscopy (EM) and immunoelectron microscopy (IEM) examination for detection of Fas-R expression on lymphocytes were also done. sFas, liver function tests, serologic markers for viral hepatitis, and serum alpha-fetoprotein level (alpha-FP) were done. 


\section{Early Detection of Hepatocellular Carcinoma on top of Liver Cirrhosis....}

\section{Results:}

The sFas in both HCC and $\mathrm{CHC}$ with cirrhosis patients were significantly higher than those of normal controls and $\mathrm{CHC}$ without cirrhosis $(\mathrm{P}<0.01)$, but there was no significant difference between the cirrhosis and HCC patients. Positive hepatic expression of both Fas and Fas-L were significantly increased in the diseased groups $(\mathrm{p}<0.01)$ compared to the control specimens. A progressive Fas and FasL increase from $\mathrm{CHC}$ without cirrhosis to $\mathrm{CHC}$ with cirrhosis followed by a decline from the latter to HCC. Apoptotic Fas and Fas-L proteins expression was significantly increased with the necroinflammatory activity and the advancement of fibrosis. There was a non-significant negative correlation between sFas and hepatic Fas. In addition a significant over expression of Fas-R on separated lymphocytes was associated with a higher frequency of apoptotic cell death as detected by EM examination.

\section{Conclusion:}

The Fas receptor/ligand system was significantly involved in the process of liver cirrhosis converting into HCC. Down-regulation of Fas expression, up-regulation of Fas-L expression in hepatocytes and elevation of serum sFas level were important in tumor evasion from immune surveillance and in hepatic carcinogenesis.

Key Words: hepatocellular carcinoma, cirrhosis, Fas, Fas ligand, hepatitis C

Abbreviations:

Hepatitis $\mathrm{C}$ virus (HCV), hepatocellular carcinoma (HCC), chronic hepatitis C (CHC), Fas Ligand (FasL), Fas receptor (FasR), serum soluble Fas (sFas), alpha-fetoprotein level (alphaFP),

\section{Introduction}

Hepatitis C Virus (HCV) is recognized as a major threat to global public health. An estimated 170 million people worldwide are infected, most of them are chronically infected and at risk for liver cirrhosis and hepatocellular carcinoma (HCC) (Coulon et al., 2010). Immunophenotyping of intrahepatic infiltrating inflammatory cells in chronic hepatitis $\mathrm{C}$ (CHC) patients showed a predominance of T-lymphocytes cells, with a significant proportion of CD4+ and CD8+ cells, suggesting that the host immune system is involved in liver disease pathogenesis (Onji et al., 1992). The continued viral replication and persistent attempt by a less than optimal immune response to eliminate $\mathrm{HCV}$ infected cells are implicated in hepatocyte aberrations, accumulation of chromosomal damage and possibly initiation of hepatic carcinogenesis (Ahn et al., 2004). 


\section{Olfat Hammam et Al}

Our immune system, charged with the function of cancer surveillance, has complex and efficient capability to clear genetically altered cells that have undergone malignant transformation. Tumor cells must develop strategies to avoid clearance by the immune system to survive, expand their populations and metastasize (Patel, 1999). The identification of the "death factors" including Fas and its Ligand (Fas-L) as a major regulator of both apoptosis and immune function has provided insight into an attractive mechanism of tumor escape from immune clearance (Nagata, 1997).

Fas and Fas-L are transmembrane proteins of the tumor necrosis factor family of receptors and ligands. Engagement of Fas by Fas-L triggers a cascade of well-characterized intracellular signaling events that culminate in cell death by apoptosis (Nagata and Goldstein, 1995). Fas receptors are widely expressed in normal and diseased tissues. It has been implicated in tumor progression of several cancers (ViardLeveugle et al., 2003;Bebenek et al., 2008).

Fas-L is expressed mainly in cytotoxic T-lymphocyte (Suda et al., 1993), immune privileged sites (Griffith et al., 1995) and in various tumors where specific cytotoxic T-cell clones are produced (Lee et al., 1998). Fas-L over expression was found to be related to advanced stage in many tumors (ViardLeveugle et al., 2003;Pryczynicz et al., 2010).

Apoptosis is tightly regulated throughout a variety of mechanisms, one of which is postulated to be the production of sFas which is an antagonistic decay protein similar to Fas, except that it lacks the transmembrane domain. It normally binds to FasL, thus blocking the signaling of the membrane-bound form of Fas. Elaboration of sFas by tumor cells, by alternative mRNA splicing, may contribute to resistance to Fas-mediated apoptosis (Nagao et al., 1999).

Therefore, due to the importance of the Fas system members (Fas, FasL and sFas), this study was designed to assess the hepatic tissue expression of Fas/FasL, Fas receptor (FasR) expression on $\mathrm{T}$ lymphocytes using electron microscope (EM) and immunoelectron microscope (IEM) examination and the circulating serum level of sFas in chronic hepatitis $\mathrm{C}$ liver disease, to analyze the role of these factors in the multistep process of fibrosis/carcinogenesis and the possible use of the serum marker as possible candidate biomarkers for an early detection of HCC.

\section{Patients and Methods}

This study enrolled 90 chronic HCV patients (54 males and 36 females), age range between 24-66 years with a 


\section{Early Detection of Hepatocellular Carcinoma on top of Liver Cirrhosis....}

mean of $48.32 \pm 7.65$ admitted to the Hepatology and Gastroenterology Department at Theodor Bilharz Research Institute (TBRI) and Kasr Al Aini Hospital. Liver and tumor specimens were taken by surgery and endoscopy from hepatectomies. They included 30 cases of chronic hepatitis $\mathrm{C}$ virus infection without hepatic cirrhosis, 30 cases with hepatic cirrhosis and 30 cases with HCC. Patients with liver disease of other etiology were excluded. The diagnosis of cirrhotic patients was made on the basis of clinical history, clinical examinations, laboratory findings, gastroscopy and ultrasonography. In addition, ten control liver biopsies were taken from age- and sex-matched individuals undergoing laparoscopic cholecystectomy (7 males and 3 females, age range between 31-45 years with a mean of 42.21 \pm 4.54$)$. Written informed consent was obtained from all participants and the TBRI local ethical committee approved the study.

\section{Sampling}

Blood samples of $8 \mathrm{ml}$ were collected into sterile endotoxin-free vacuum blood collection tubes on potassium EDTA. The peripheral blood mononuclear cell (PBMNC) layer was separated using Ficoll Hypaque (Seromid Biochrom, Berlin, Germany) density gradient centrifugation and washed 3 times with Hank's balanced salt solution (HBSS) without $\mathrm{Ca} 2+$ and $\mathrm{Mg} 2+$ ions (Helmy et al, 2007). These cells were prepared for
EM examination using agarose cell block technique in addition to the IEM examination. Another $2 \mathrm{ml}$ of blood were withdrawn into plain tube and centrifuged shortly after clot formation. All samples were stored at $-70^{\circ} \mathrm{C}$ in aliquots and used for analysis of sFas.

Formalin-fixed and paraffin embedded tissues from tumor samples were used for immunohistochemical analysis of Fas and FasL. Liver biopsies are analyzed according to a histological METAVIR (Bedossa and Poynard, 1996) scoring system. Using two separate scores, one for necroinflammatory grade (A for activity) A1: minimal activity, A2: moderate activity, A3: severe activity and another for the stage of fibrosis (F) which scores fibrosis from F0-F4, Starting with a score of F1 with minimal fibrosis and increasing till F4 signifies advanced fibrosis.

\section{Routine laboratory investigations:}

Complete haemogram using automated haemogram (ACT Differential, Beckman, France). Liver function tests were carried out using commercially available kits. Circulating anti-HCV antibodies were detected using Murex enzyme immunoassay kit (Murex antiHCV, Version V; Murex Diagnostics; Dartford, England). The presence of $\mathrm{HCV}$ RNA in patients' sera was detected by realtime polymerase chain reaction (PCR) using the Amplicor test (Roche Diagnostic Systems; Meylan, France). 


\section{Olfat Hammam et al}

Immunohistochemical analysis

Immunohistochemical reaction was performed using an avidin biotin complex (ABC) immunoperoxidase technique according to Hsu and Raine, 1981 using anti human Fas and FasL on paraffin sections; dewaxed in xylene and hydrated in descending grades of ethanol. Endogenous peroxidase activity was quenched by incubation in $3 \%$ hydrogen peroxide in $100 \%$ methanol for $20 \mathrm{~min}$. Antigen retrieval was performed by microwaving the sections in citrate buffer (PH 6.0) for $15 \mathrm{~min}$ at $700 \mathrm{~W}$. Sections were incubated overnight at $4{ }^{\circ} \mathrm{C}$ with the anti-human primary antibodies against Fas and Fas Ligand (purchased from Santa Cruz Biotechnology Inc.; Santa Cruz, USA) monoclonal antibody, diluted at $1: 100,1: 150$ respectively in BPS. Next day, after thorough washing in PBS, the sections were incubated with streptavidinbiotin-peroxidase preformed complex and using a peroxidase/DAB (3, 3'diaminobenzidine) enzymatic reaction. Staining is completed by 5-10 minutes results in a

brown-colored precipitate at the antigen site. The cell nuclei were counterstained with Mayer's hematoxylin. The cover slips were mounted using Dpx.

Positive and negative control slides for each marker were included within each session. As a negative control, liver tissue section was processed in the above mentioned sequences but the omission of the primary antibody and PBS was replaced.

The scoring of Fas and FasL in liver tissue was based on intensity and extensiveness (by percentage population) of the positively stained cells. Both parameters were scored on a scale of $0-3$ as follows:

\section{(1)Intensity:}

$0=$ negative staining $(-)$

$1=$ weakly positive staining $(+)$

$2=$ moderately positive staining $(++)$

$3=$ strongly positive staining $(+++)$

(Chen et al, 2003)

\section{(2) Range:}

$0=$ negative

$1=$ positive staining in $<10 \%$ of cells

$2=$ staining in $10 \%-50 \%$

$3=$ staining in $>50 \%$ of cells

(Itoi et al, 2004)

Liver sections were examined by Zeiss light microscopy at power X400, X200 and X100 for both markers; the number of positively stained cells with the highest expression was semi-quantitatively recorded within ten successive fields were counted / section and the final value represents the mean. Zero percentage was given to unstained sections. 
Early Detection of Hepatocellular Carcinoma on top of Liver Cirrhosis....

Measurements of Serum Soluble Fas (sFas) Levels

Serum Fas levels were assayed using a sandwich enzyme-linked immune-sorbent assay kit (Biosource International, Camarillo, California, USA) according to the manufacturer's instructions. Briefly, diluted serum samples and standard were added in duplicate to 96-well microtitre plates coated with Fas antibody and another biotinylated Fas antibody was added. The plate was incubated at room temperature for $1 \mathrm{~h}$, followed by incubation with a streptavidin horseradish peroxidase conjugate for 30 min. A solution including the stabilized chromogen was added to each well and incubated for $30 \mathrm{~min}$ at room temperature. The reaction was stopped by adding $1 \mathrm{~N}$ sulfuric acid. The optical density was measured at $450 \mathrm{~nm}$ wavelength using an ELISA reader (Bio Rad). The concentration of sFas in serum samples was determined from the standard curve. All assays were conducted in duplicates, and the mean concentration of $\mathrm{sFas}$ was calculated.

Electron Microscopic and Immunoelectron Microscopic Examination of Peripheral Blood Monocytic Cells (PBMNCs) using Agarose Cell Block Technique (Mansy, 2004).

Solidified agarose blocks of separated cells were refixed in buffered
4\% glutaraldehyde for 1 hour then postfixed in $2 \%$ osmic acid for 1 hour, dehydrated in ascending alcohol, then infiltrated and embedded in epoxy resin. Ultrathin sections were performed using Leica Ultramicrotome (Leica Microsystems GmbH, Ernst-Leitz-Strasse, Austria). The sections were stained with uranyl acetate and lead citrate and examined using Philips Microscopic Electron Microscope 208 S (Eindhoven, The Netherlands). IEM examination was performed on other part of separated cells using rabbit polyclonal anti-Fas antibodies (Maixin-Bio) as above method of Immunohistochemical analysis then processed into agarose cell block and prepared for EM examination as above.

\section{Statistical analysis}

Statistical evaluation of results was done using SPSS computer program (version 12 windows). Results were expressed as mean \pm standard deviation (SD) or number (\%). Comparison between the mean values of different parameters in the different groups were performed using one way analysis of variance (ANOVA) with post hoc using least significant difference. Correlation between parameters was performed using Spearman's rank correlation coefficient ( $\mathrm{r}$ ) (Petei and Sabin, 2001). $P$ value $<0.05$ was considered significant and $<0.01$ was considered highly significant. 
Early Detection of Hepatocellular Carcinoma on top of Liver Cirrhosis....

\section{Results:}

Hepatic Expression of Fas/ FasL antigen

Fas/FasL protein was observed in the membrane \pm cytoplasm of hepatocytes with occasional perinuclear staining. In the current study, normal liver specimens showed faint Fas protein expression and no detectable FasL protein expression. Both antigens were significantly increased in the diseased groups $(p<0.01)$ compared to the control specimens (Table I, II and III). In CHC, Fas was detected among infiltrating lymphocytes at the advancing edges of piecemeal necrosis (interface hepatitis). Moreover, FasL protein was expressed dominantly in the infiltrating mononuclear cells in the portal area and hepatic sinusoid. Our data (Table I, II and III) showed a progressive Fas and FasL increase from $\mathrm{CHC}$ without cirrhosis to CHC with cirrhosis. Hepatic Fas expression was significantly decreased on comparing $\mathrm{HCC}$ to cirrhotic patients $\mathrm{p}<0.5$. On the other hand FasL expression in HCC group showed a non significant difference compared to $\mathrm{CHC}$ with cirrhosis.

In CHC, apoptotic Fas and FasL proteins expression was significantly increased with the necroinflammatory activity and the advancement of fibrosis according to the METAVIR scoring systems (table IV and V) (Figures 1and 2).

\section{Serum level of sFas}

Concentrations of studied parameter in CHC, HCC patients and normal controls are shown in Table I, IV, and V. The serum level of sFas in both HCC and cirrhotic patients were significantly higher than those of normal controls and $\mathrm{CHC}$ without cirrhosis $(\mathrm{P}<0.01)$, but there was no significant difference between cirrhosis and HCC patients.

Correlation analysis between different studied parameters was demonstrated in (table VI). 


\section{Olfat Hammam et Al}

Table (I): Mean \pm SD of the studied parameters in all groups

\begin{tabular}{|l|l|l|l|l|}
\hline & \multicolumn{1}{|c|}{$\begin{array}{c}\text { Control } \\
(\mathrm{n}=10)\end{array}$} & $\begin{array}{c}\text { CHC without } \\
\text { cirrhosis } \\
(\mathrm{n}=30)\end{array}$ & $\begin{array}{c}\text { CHC with cirrhosis } \\
(\mathrm{n}=30)\end{array}$ & $\begin{array}{c}\text { HCC } \\
(\mathrm{n}=30)\end{array}$ \\
\hline Tissue Fas & $1.8 \pm 0.8$ & $25.0 \pm 5.74^{\mathrm{a}}$ & $61.36 \pm 4.69^{\mathrm{ab}}$ & $27.3 \pm 5.6^{\mathrm{ac}}$ \\
\hline Tissue FasL & $00 \pm 00$ & $33.46 \pm 11.91^{\mathrm{a}}$ & $49.83 \pm 8.20^{\mathrm{ab}}$ & $45.32 \pm 6.41^{\mathrm{ab}}$ \\
\hline $\begin{array}{l}\text { sFas } \\
\text { pg/ml }\end{array}$ & $165.5 \pm 45.6$ & $238.27 \pm 135.29^{\mathrm{a}}$ & $814.94 \pm 362^{\mathrm{ab}}$ & $762.18 \pm 437^{\mathrm{ab}}$ \\
\hline
\end{tabular}

${ }^{a} p$ Statistically significant from control group $(p<0.01)$.

${ }^{\mathrm{b}} p$ Statistically significant from CHC without cirrhosis group $(p<0.01)$.

${ }^{c} p$ Statistically significant from cirrhosis group $(p<0.01)$

Table (II): Tissue Expression of Fas Immunostain in Liver Tissue

\begin{tabular}{|c|c|c|c|c|c|c|c|c|}
\hline \multirow[t]{2}{*}{ Histopathologic Diagnosis (n) } & \multicolumn{2}{|c|}{ Positive Cases } & \multicolumn{3}{|c|}{ Range $\%$} & \multicolumn{3}{|c|}{ Intensity\% } \\
\hline & No & $\%$ & $<10 \%$ & $10 \%-50 \%$ & $>50 \%$ & + & ++ & +++ \\
\hline Controls (10) & 2 & 20 & 2 & - & |- & 2 & - & - \\
\hline CHC without cirrhosis (30) & 10 & $33.3^{\mathrm{a}}$ & 2 & 8 & |- & 3 & 7 & - \\
\hline CHC with cirrhosis (30) & 16 & $54.3^{\mathrm{ab}}$ & 5 & 6 & 5 & $T$ & 8 & 4 \\
\hline HCC (30) & 13 & $43.3^{\mathrm{abc}}$ & 1 & 5 & 7 & - & 6 & 7 \\
\hline
\end{tabular}

${ }^{\mathrm{a}} \mathrm{p}<0.01$ significant difference relative to control group.

${ }^{b} p<0.05$ significant difference relative to $\mathrm{CHC}$ without cirrhosis.

${ }^{c} \mathrm{p}<0.05$ significant difference relative to $\mathrm{CHC}$ with cirrhosis.

Table (III): Tissue Expression of FasL Immunostain in Liver Tissue

\begin{tabular}{|c|c|c|c|c|c|c|c|c|}
\hline \multirow[t]{2}{*}{ Histopathologic Diagnosis (n) } & \multicolumn{2}{|c|}{ Positive Cases } & \multicolumn{3}{|c|}{ Range $\%$} & \multicolumn{3}{|c|}{ Intensity\% } \\
\hline & No & $\%$ & $<10 \%$ & $10 \%-50 \%$ & $>50 \%$ & + & ++ & +++ \\
\hline Controls (10) & 0 & 0 & - & - & - & - & - & - \\
\hline CHC without cirrhosis (30) & 13 & $43.3^{\mathrm{a}}$ & 3 & 10 & - & 8 & 5 & - \\
\hline CHC with cirrhosis (30) & 17 & $56.6^{\mathrm{ab}}$ & 6 & 6 & 5 & 4 & 8 & 5 \\
\hline HCC (30) & 16 & $53.3^{\mathrm{ac}}$ & 2 & 7 & 7 & - & 7 & 9 \\
\hline
\end{tabular}

${ }^{a} \mathrm{p}<0.01$ significant difference relative to control group.

${ }^{b} \mathrm{p}<0.05$ significant difference relative to $\mathrm{CHC}$ without cirrhosis.

${ }^{c} \mathrm{p}<0.05$ significant difference relative to $\mathrm{CHC}$ with cirrhosis. 


\section{Olfat Hammam et Al}

Table (IV): Mean \pm SD of the studied parameters according to METAVIR activity scoring system in $\mathrm{CHC}$ with or without cirrhosis groups.

\begin{tabular}{|c|c|c|c|}
\hline & A1 $(\mathbf{n = 2 8})$ & A2 $(\mathbf{n = 1 8})$ & $\mathbf{A 3}(\mathbf{n}=\mathbf{1 4})$ \\
\hline Tissue Fas & $23.57 \pm 5.75$ & $27.500 \pm 3.54$ & $43.00 \pm 4.43^{\mathrm{ab}}$ \\
\hline Tissue FasL & $17.14 \pm 4.23$ & $20.00 \pm 7.32$ & $45.40 \pm 6.42^{\mathrm{ab}}$ \\
\hline S Fas pg/ml & $210.4 \pm 23.2$ & $395.8 \pm 41.4^{\mathrm{a}}$ & $447.5 \pm 51.7^{\mathrm{ab}}$ \\
\hline
\end{tabular}

${ }^{\mathrm{a}} p$ Statistically significant from A1 group $(p<0.01)$.

${ }^{\mathrm{b}} p$ Statistically significant from A2 group $(p<0.01)$.

Table (V): Mean \pm SD of he studied parameters according to METAVIR fibrosis scoring system in $\mathrm{CHC}$ with or without cirrhosis groups.

\begin{tabular}{|c|c|c|c|c|}
\hline & $\begin{array}{c}\text { F1 } \\
(\mathbf{n = 2 4})\end{array}$ & $\begin{array}{c}\text { F2 } \\
(\mathbf{n = 1 5})\end{array}$ & $\begin{array}{c}\text { F3 } \\
(\mathbf{n = 1 4})\end{array}$ & $\begin{array}{c}\text { F4 } \\
(\mathbf{n = 7})\end{array}$ \\
\hline Tissue Fas & $17.40 \pm 6.21$ & $19.759 \pm 9.76$ & $23.04 \pm 2.08^{\mathrm{a}}$ & $33.28 \pm 5.16^{\mathrm{abc}}$ \\
\hline Tissue FasL & $15.160 \pm 5.02$ & $18.75 \pm 1.30$ & $21.41 \pm 2.28^{\mathrm{ab}}$ & $28.42 \pm 6.06^{\mathrm{ab}}$ \\
\hline s Fas pg/ml & $200.4 \pm 47.1$ & $250.3 \pm 33.6$ & $260.4 \pm 54.7^{\mathrm{a}}$ & $340.3 \pm 65.4^{\mathrm{abc}}$ \\
\hline
\end{tabular}

${ }^{\mathrm{a}} p$ Statistically significant from $\mathrm{F} 1$ group $(p<0.01)$.

${ }^{\mathrm{b}} p$ Statistically significant from $\mathrm{F} 2$ group $(p<0.01)$.

${ }^{c} p$ Statistically significant from F3 group $(p<0.01)$.

Table (VI): Correlation of tissue expression of different parameters in studied groups

\begin{tabular}{|c|c|c|}
\hline Parameters & $\begin{array}{c}\text { Correlation } \\
\text { coefficient }(\mathbf{r})\end{array}$ & P value \\
\hline Tissue Fas versus Tissue FasL & 0.753 & $<0.001$ \\
\hline Tissue Fas versus sFas pg/ml & -0.321 & $<0.05$ \\
\hline Tissue FasL versus sFas $\mathbf{~ p g} / \mathbf{m l}$ & 0.682 & $<0.01$ \\
\hline
\end{tabular}



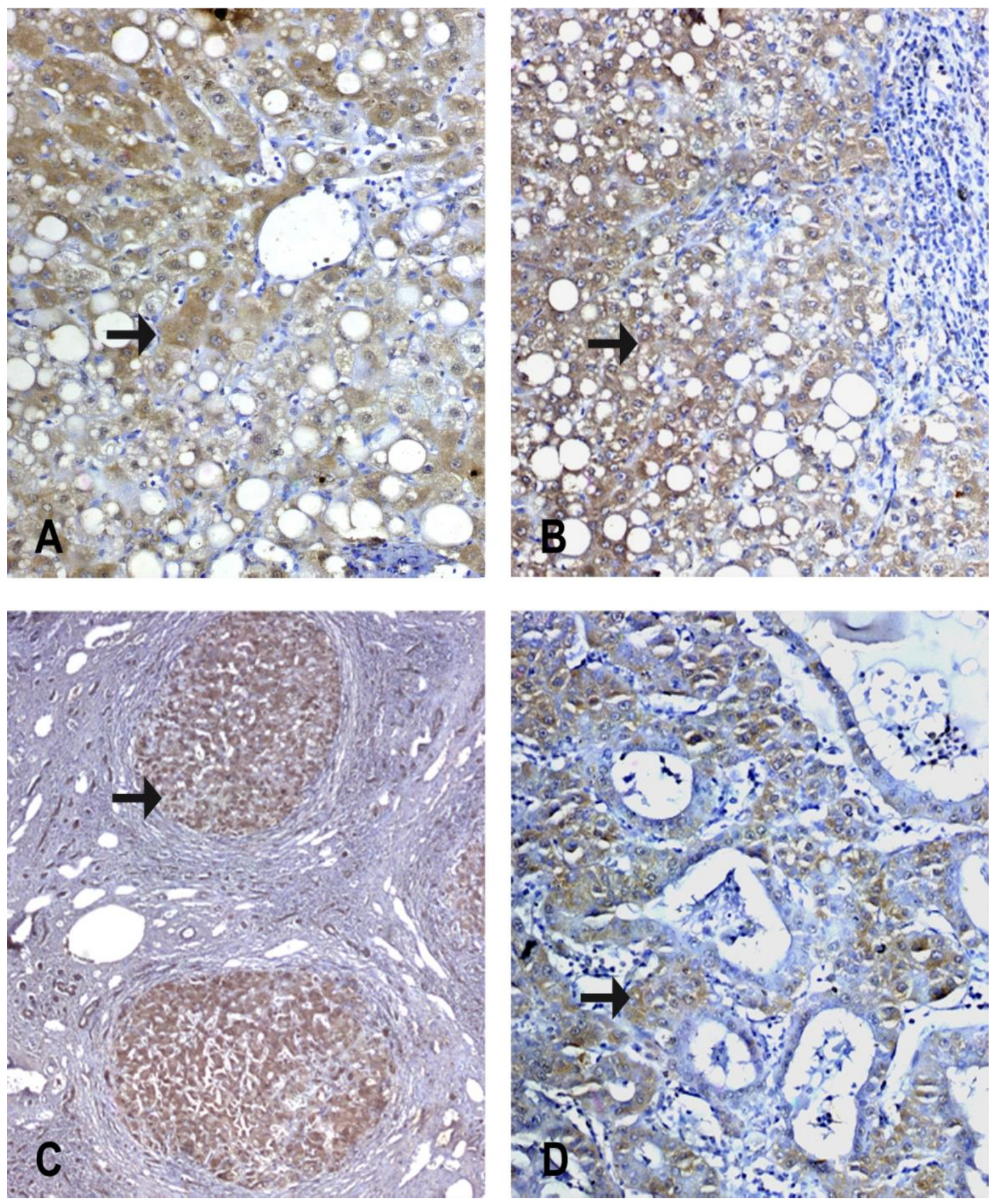

Figure 1: Immunostain for Fas monoclonal antibody, A) a case of $\mathrm{CHC}$ without cirrhosis, A1F1 showing mild expression of Fas as membranous \pm cytoplasmic stain in the hepatocytes and in lymphocytes at the periportal area (IHC, DAB, X 200).B) a case of CHC with cirrhosis, A2F2, showing moderate expression of Fas as membranous \pm cytoplasmic stain in the hepatocytes and in lymphocytes at the periportal area (IHC, DAB, X 200).C) a case of CHC with cirrhosis, A2F3, showing cirrhotic nodule with moderate to marked expression of Fas as membranous \pm cytoplasmic stain in the hepatocytes and in lymphocytes at the periportal area ( IHC, DAB, X 100). D) a case of moderately differentiated HCC showing mildly expressed Fas in the cytoplasm of hepatocytes ( IHC, DAB, X400) 


\section{Olfat Hammam et al}
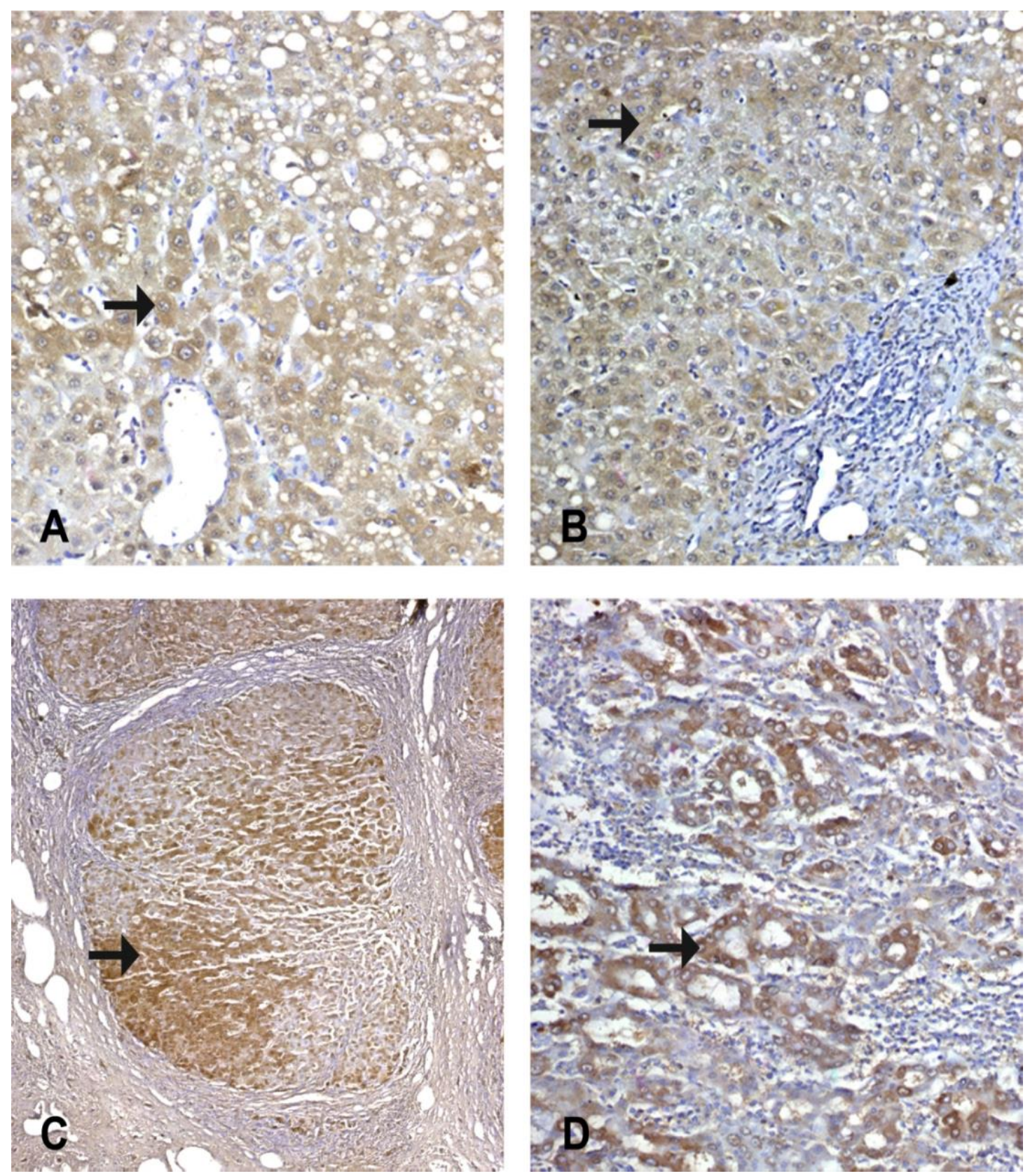

Figure 2: Immunostain for Fas ligand monoclonal antibody, A) a case of $\mathrm{CHC}$ without cirrhosis A1F1 showing mild expression of Fas ligand as cytoplasmic stain in the hepatocytes (IHC, DAB, X200), B) a case of $\mathrm{CHC}$ with cirrhosis $\mathrm{A} 2 \mathrm{~F} 2$ showing moderate expression of Fas ligand as cytoplasmic stain in the hepatocytes (IHC, DAB, X200), C) a case of CHC with cirrhosis showing cirrhotic nodule with moderate expression of Fas ligand as cytoplasmic stain in the hepatocytes. (IHC, DAB, X100), D) a case of moderately differentiated HCC showing moderate expressed Fas ligand in the cytoplasm of hepatocytes (IHC, DAB, X200).

\section{Discussion}

Apoptosis is central for the control and elimination of viral infections. In chronic HCV infection, enhanced hepatocyte apoptosis and up-regulation of the death inducing ligands occur. 


\section{Early Detection of Hepatocellular Carcinoma on top of Liver Cirrhosis....}

Nevertheless, HCV infection persists in the majority of patients (Bantel and Schulze, 2003). The impact of apoptosis in chronic HCV infection is not well understood. It may be harmful by triggering liver fibrosis, or essential in interferon induced $\mathrm{HCV}$ elimination (Fisher et al., 2007). In addition, escape from the immune surveillance may play an important role in tumor outgrowth and metastasis.

The Fas receptor/ligand system including soluble forms is the most important apoptotic initiator in the liver (Pelli et al., 2007). Dysregulation of this pathway may contribute to abnormal cell proliferation and cell death (Kornmann et al, 2000) and is regarded as one of the mechanisms preventing the immune system from rejecting the tumor cells (Nagao et al, 1999). In this study the immunohistochemical expression of Fas and FasL was determined using specific monoclonal antibodies. In normal liver, Fas was faintly expressed on cytoplasm and membranes of hepatocytes, while FasL was negative. This result was consistent with those of Roskamset et al. (2000) and Leithauser et al.( 1993). Data also showed increase expression of Fas receptor and ligand in hepatocytes in liver specimens from $\mathrm{CHC}$ patients with and without cirrhosis as compared with controls. Hepatic Fas expression was found to be elevated in chronic hepatitis B (Mochizuki et al, 1996), chronic hepatitis
C (Hiramatsu et al., 1994) and (El Bassiouny et al., 2008) and acute liver failure (Galle et al, 1995). Moreover, a progressive Fas and FasL increase from $\mathrm{CHC}$ without cirrhosis to $\mathrm{CHC}$ with cirrhosis was also observed (Bortolami et al., 2008). Our results suggest that "suicide" and "fratricide" mechanisms proposed by Galle et al.( 1995) in the study of alcoholic liver cirrhosis may also work in liver cirrhosis after viral hepatitis $\mathrm{C}$ and may explain the mechanism by which apoptosis might be involved in the pathogenesis of liver cirrhosis. "Fratricide", induced by ligation of Fas receptor and FasL expressed on the surface of adjacent cells while "suicide", induced by binding of FasL expressed by hepatocytes to Fas on the surface of themselves.

According to METAVIR activity score system, the up regulation of hepatic Fas expression demonstrated in our study in CHC patients was in accordance with the severity of liver inflammation. Similar results were obtained by Hayashi and Mita, 1997. The histological activity index (HAI) revealed more expression of Fas antigen in liver tissues with active inflammation than in those without active inflammation (El Bassiouny et al., 2006). When HCV-specific T-cells migrate into hepatocytes and recognize the viral antigen via the T-cell receptor, they become activated and express FasL that can transduce the apoptotic death signal to 


\section{Olfat Hammam et al}

Fas-bearing hepatocytes (Hayashi and Mita, 1997) and (Galle et al, 1995). This was proved in our study by the prominent expression of FasL protein in the infiltrating mononuclear cells in the portal area and hepatic sinusoid .Thus, the Fas system plays an important role in liver cell injury by $\mathrm{HCV}$ infection. Our results also demonstrate that the expression of Fas and FasL increased in the course of liver fibrosis. Several studies have demonstrated increased expression of Fas and FasL in the course of liver fibrosis, which is the most serious consequence of chronic liver injury (El Bassiouny et al, 2008), (Zhang et al, 2006) and (Akazawa and Gores, 2007). Experimentally, the up regulation of Fas expression occurs on stimulation with interferon-gamma released from T-cells (Kawamura et al., 2000). Hepatic fibrogenesis accompanied by hepatocellular necrosis and inflammation was also suggested to be caused by cytokines and transforming growth factor-beta-1 released by Kupfer cells and infiltrating T-lymphocytes (EI Bassiouny et al, 2008).

Because hepatic fibrosis is associated with a high incidence of HCC, it was speculated that Fas expression may be involved in the incidence of $\mathrm{HCC}$ (Hirashima et al, 2002) and (Kamegaya et al, 2005). In HCC liver biopsies, FasL showed cytoplasmic positivity in hepatocytes in areas of interface hepatitis. Strong expression of Fas as well as FasL in the hepatocytes immediately adjacent to HCC was a constant finding. Within the HCC biopsies, FasL expression was variable, but present only in a minority of cells. Fas varied from a diffuse honeycomb pattern to focal positivity in occasional cells.

In recent years, there is accumulating evidence showing that $\mathrm{sFas}$ plays an important role in modulation of apoptosis (Hiramatsu et al., 1994). sFas was capable of inhibiting hepatic apoptosis by binding to FasL or anti-Fas anti-bodies in competition with membrane-bound Fas. sFas protein, composed of the extra cellular region of Fas receptor and $\mathrm{Fc}$ sequence of human $\operatorname{IgG}$, inhibited the activity of cytotoxic T-lymphocytes in a dose-dependent manner (Peng et al, 2001). Midis et al.( 1996) reported that patients with non-haematopoietic malignancies exhibit elevated sFas levels compared to normal controls and that sFas can be synthesized and released in the culture supernatants of human solid tumor explants. They also found that the relative elevation of sFas levels in nonhaematopoietic cancer patients might be in consistence with both disease stage and tumor burden. Many researchers reported that serum sFas levels in patients with HCC were significantly higher than those in healthy adults (El Bassiouny et al, 2008) and (Peng et al, 2001). Judo et al, 1998 also reported that sFas level was related with the number of tumor nodules, 
but not with its size of the solitary nodule. In patients with solitary HCC nodule, serum sFas levels fell rapidly after surgical resection, and went undetectable in one week. This evidence suggested that sFas was generated by tumor cells or at least tumor related. sFas mediated a prereceptorial resistance of Fas-expressing hepatocytes by antagonizing FasL killing of infiltrating CTLs. Fas-bearing tumor cells thus were saved by sFas from the fate of apoptosis and escape the immune surveillance. Our data revealed significantly higher serum $\mathrm{sFas}$ levels in HCC patients than those in healthy adults, but shown no significant difference between the levels in HCC and liver cirrhosis patients. This phenomenon may be due to relatively high expression of FasL in HCC cells, and sFas cleaved by metalloproteinases from the transmembrane domain might be capable of binding to sFas, thus accuracy of the measurement was influenced. A linear correspondence between liver tissue expression and serum levels of $\mathrm{sFas}$ was also detected.

In Conclusion, apoptosis and the Fas system were significantly involved in the process of liver cirrhosis converting into hepatocellular carcinoma. Downregulation of Fas expression, up regulation of FasL expression in hepatocytes and elevation of serum $\mathrm{sFas}$ level were important in tumor evasion from immune surveillance and in hepatic carcinogenesis.
Therefore warranted and draw the attention to the use of these components of the Fas system as an attractive target for anticancer therapy. In addition, the linear correspondence between liver tissue expression of Fas and its serum levels suggest that they could be considered as a predictive marker for tumorogenesis in HCC.

\section{References}

Ahn J, Chung KS, Kim DU, Won M, Kim L, Kim KS, Nam M, Choi SJ, Kim HC, Yoon M, Chae SK and Hoe KL (2004): Systematic identification of hepato cellular proteins interacting with NS5A of the hepatitis $\mathrm{C}$ virus. J Biochem Mol Biol; 37: 741-748.

Akazawa Y and Gores GJ (2007): Death receptor mediated liver injury. Semin Liver Dis; 27: 327-338.

Bantel H and K Schulze O (2003): Apoptosis in hepatitis $\mathrm{C}$ virus infection. Cell Death Differ; 10: 48-58.

Bębenek M1, Duś D and Koźlak J (2008): Fas expression in primary breast cancer is related to neoplastic infiltration of perilymphatic fat. Advances in Medical Sciences; 53(1): 49-53.

Bedossa P and Poynard T (1996): An Algorithm for the Grading of Activity in Chronic Hepatitis C. Hepatology; 24:289-293.

Bortolami M, Kotsafti A, Cardin $\mathbf{R}$ and Farinati F (2008): Fas / FasL system, IL-1beta expression and apoptosis in chronic 
HBV and HCV liver disease. J Viral Hepat; 15(7):515-522.

Chen NL, Bai L and Deng T (2003): Study on pathway of apoptosis in chronic liver disease. Zhonghua Chuanranbing Zazhi; 21: 122-124.

Coulon S, Heindryck F, Geerts A, Van Steenkiste C, Colle I and Van Vlierberghe $H$ (2010): Angiogenesis in chronic liver disease and its complications. Liver International;

31 (2): 146-162.

El Bassiouny A, Nosseir M, Zoheiry M, ElAhwany E, Ghaleb A and El-Bassiouni N (2006): Immunohistochemical expression of CD95 (Fas), c-myc and epidermal growth factor receptor in hepatitis $\mathrm{C}$ virus infection, cirrhotic liver disease and hepatocellular carcinoma. APMIS; 114(6):420-427.

El Bassiouny A, El-Bassiouni N, Nosseir M, Zoheiry M, , El-Ahwany E, Salah F, Omran Z, and Ibrahim R (2008): Circulating and Hepatic Fas Expression in HCV-Induced Chronic Liver Disease and Hepatocellular Carcinoma. Medscape J Med; 10(6): 130.

Fischer R, Baumert T and Blum H (2007): Hepatitis C virus infection and apoptosis. World J Gastroenterol; 13(36): 4865-4872

Galle PR, Hofmann WJ, Walczak H, Schaller H, Otto G, Stremmel W, Krammer PH and Runkel L (1995): Involvement of the CD95 (APO-1/Fas) receptor and ligand in liver damage. J Exp Med; 182(5):1223-1230.

Griffith T, Brunter T, Fletcher S, Green D and Ferguson T (1995): Fas ligand-induced apoptosis as a mechanism of immune privilege. Science; 270:1189-1192.
Hayashi N and Mita E (1997): Fas system and apoptosis in viral hepatitis. J Gastroenterol Hepatol; 12(9-10): 223-226.

Helmy A, Hammam OA, El Lithy TR, and Wishahi MM (2007): The Role of TGF-beta-1 Protein and TGF-beta-R-1 Receptor in Immune Escape Mechanism in Bladder Cancer. Medscape J Med MedGenMed (Hematology -Oncology); 9(4):34-54.

Hiramatsu N, Hayashi N, Katayama $K$, Mochizuki K, Kawanishi Y, Kasahara A, Fusamoto H and Kamada T (1994): Immunohistochemical detection of Fas antigen in liver tissue of patients with chronic hepatitis C. Hepatology; 19(6):1354-1359.Hirashima N, Matsumoto Y, Ohono T, Kimura Y, Hasegawa I, and Ueda R (2002): Hepatic Fas protein expression might be a predictive factor for hepatocellular carcinoma development in patient with chronic hepatitis $\mathrm{C}$ undergoing interferon therapy. J Clin Gastroenterol; 34:263-267.

Hsu SM and Raine L (1981): Protein A, avidin and biotin in immunohistochemistry. $\mathrm{J}$ Histochem Cytochem; 29: 1349-1353.

Itoi T, Yamana K, Bilim VN, Takahashi K and Tomita Y (2004): Impact of frequent Bcl2 expression on better prognosis in renal cell carcinoma patients. Br J cancers; 90: 200-205.

Jodo S, Kobayashi S, Nakajima Y Matsunaga T, Nakayama $\mathbf{N}$, Ogura $\mathbf{N}$, Kayagaki N,Okumura K, Koike T. (1998): Elevated serum levels of soluble Fas/APO-1 (CD95) in patients with hepatocellular carcinoma. Clin Exp Immunol; 112:166

Kamegaya Y, Hiasa Y, Zukerberg L, et al (2005): Hepatitis C virus acts as a tumor accelerator by blocking apoptosis in a mouse 
model of hepatocarcinogenesis. Hepatology; 41:660-667.

Kawamura T, Azuma M, Kayagaki N, Shimada S, Yagita H, Okumura K (2000): Fas/Fas ligand-mediated apoptosis of murine Langerhans cells. J Dermatol Sci; 22(2):96101.

Kornmann M, Ishiwata T, Maruyama H, Beger HG and Korc M (2000): Co-expression of FAS and FAS-ligand in chronic pancreatitis: correlation with apoptosis. Pancreas; 20(2):123-128.

Lee SH, Kim SY, Lee JY, Shin MS, Dong SM, Na EY, Park WS, Kim KM, Kim CS, Kim SH and Yoo NJ. (1998): Detection of soluble Fas mRNA using in situ reverse transcriptase-polymerase chain reaction. Lab Investig; 78:453-459.

Leithäuser F, Dhein J, Mechtersheimer G, Koretz K, Brüderlein S, Henne C,Schmidt A, Debatin KM, Krammer PH and Möller

P. (1993): Constitutive and induced expression of Apo-1: a new member of the nerve growth factor/tumor necrosis factor receptor superfamily in normal and neoplastic cells. Lab Invest; 69:415-429.

Mansy S (2004): Agarose cell block: innovated technique for the processing of urine cytology for electron microscopic examination. Ultrastructural Pathology; 28:15-21.

Pelli N, Floreani A, Torre F, Delfino A, Baragiotta A, Contini P, Basso $M$ and Picciotto A (2007): Soluble apoptosis molecules in primary biliary cirrhosis: analysis and commitment of the Fas and tumor necrosis factor-related apoptosis-inducing ligand systems in comparison with chronic hepatitis C. Clin Exp Immunol; 148(1): 85-89.
Midis GP, Shen Y and Owen-Schaub LB (1996): Elevated soluble Fas (sFas) levels in nonhaematopoietic human malignancy. Cancer Res.; 56 (17): 3870-3874.

Mochizuki K, Hayashi N, Hiramatsu N, Katayama K, Kawanishi Y, Kasahara A,Fusamoto H and Kamada T (1996): Fas antigen expression in liver tissues of patients with chronic hepatitis B. J Hepatol; 24(1):1-7.

Nagao M, Nakajima $Y$, Hisanaga $M$, Kayagaki N, Kanehiro H, Aomatsu Y, Ko S, Yagita H, Yamada T, Okumura $K$ and Nakano H (1999): The alteration of Fas receptor and ligand system in hepatocellular carcinomas: how do hepatoma cells escape from the host immune surveillance in vivo? Hepatology; 30(2):413-421.

Nagata S (1997): Apoptosis by death factor. Cell; 88: 355-365.

Nagata S and Golstein P (1995): The Fas death factor. Science; 267:1449-1456.

Onji M ,Kikuchi T, Kumon I, Masumoto T , Ndano S , Kajino K, Horikee N and Ohta Y(1992): Intrahepatic lymphocyte subpopulations and HLA class I antigen expression by hepatocytes in chronic hepatitis C. Hepatogastroenterology; 39: 340-343.

Patel T (1999): Immune Escape in Hepatocellular Cancer: Is a Good Offense the Best Defense? Hepatology; 30(2): 576-578.

Peng Z, Tang H, Ling Y and Han G (2001): Apoptosis and Fas system are significantly involved in the process of liver cirrhosis converting into hepatocellular carcinoma. J Tongji Med Univ; 21(2):126-129 


\section{Olfat Hammam et al}

Petei A and Sabin C (2001): Medical statistics at Glance. Blackwell Science LTD, USA, London 2nd (Ed).

\section{Pryczynicz A, Guzińska-Ustymowicz K and}

Kemona A (2010): Fas/FasL expression in colorectal cancer. An Immunohistochemical study. Folia Histochem Cytobiol; 48(3): 425-9.

Roskams T, Libbrecht L, Van Damme B and Desmet V (2000): Fas and Fas ligand: strong co-expression in human hepatocytes surrounding hepatocellular carcinoma; can cancer induce suicide in peritumoural cells? J Pathol; 191(2):150-153.

Suda T, Takashi T, Goldstein R and Nagata S (1993): Molecular cloning and expression of the Fas ligand, a novel member of the tumor necrosis factor family. Cell; 75:1169-1178.
Viard-Leveugle I, Veyrenc S, French LE, Brambilla C and Brambilla E (2003): Frequent loss of Fas expression and function in human lung tumors with over expression of FasL in small cell lung carcinoma. J Pathol; 201 (2): 268-77.

Zhang $L$, Wang $X$, Zheng $W$ and Shi $M$ (2006): The effects of interleukin-10 on the expression of Fas and FasL in rat hepatic stellate cells. Med Chem; 2: 611-616. 
التثخيص المبكر لأورام الكبد فى حالات تليف الكبد: دورمستقبلة فاس و مشتقاتها و مركبها الترابطى

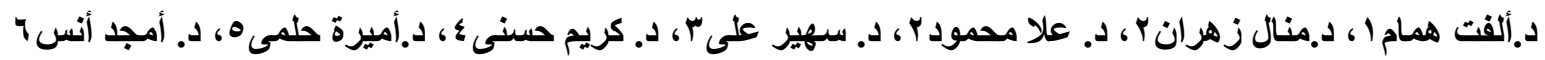
1 - قسم الباثولوجية، معهد تيودور للأبحاث، الجيزة، جمهورية مصر العربية

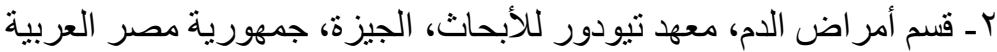

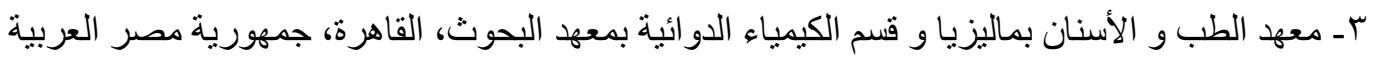

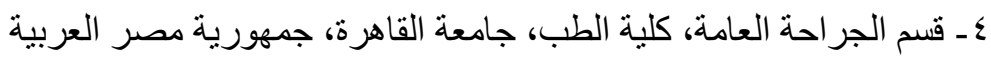

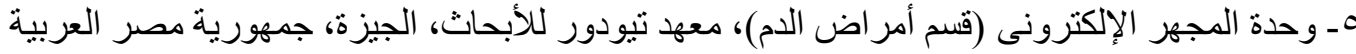

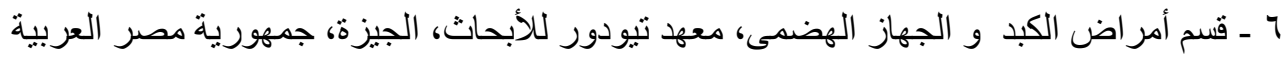

من مضاعفات إلتهاب الكبد الحموي الناتج من الإصابة بفيروس سي تولد سرطان الكبد. تكاثر الفيروسات و محاو لات

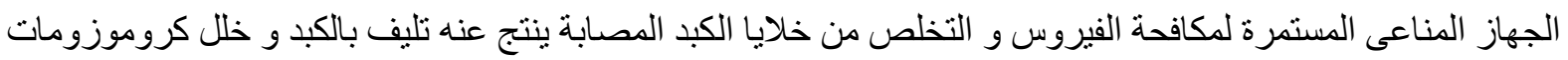

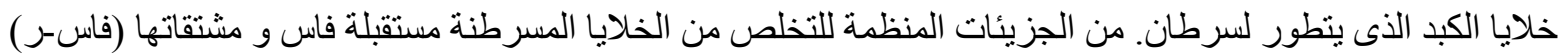

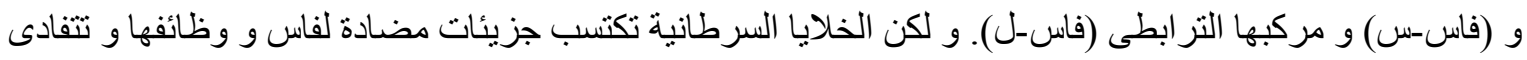

\section{هدف البحث:}

قياس جزيئات مستقبلة فاس و مركبها الترابطى (فاس-ل) فى خلايا الكبد و مشتقاتها (فاس-س) فى الدم و (فاس-ر ) على لئ

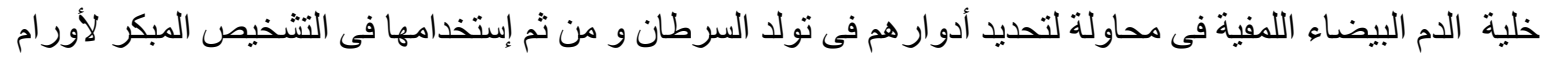
الكبد و إستخدامها كهذف للعلاج الكيماوى.

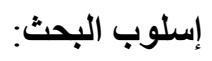

البحث تضمن مائة عينة، من حالات فى معهد تيودور بلهارزلأبحاث بالجيزة و القصر العينى بجمهورية مصر العربية.

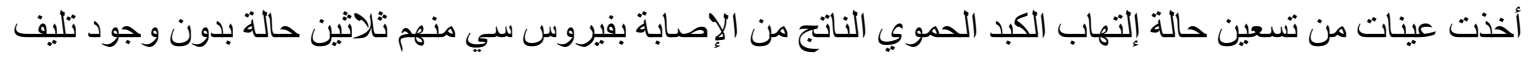

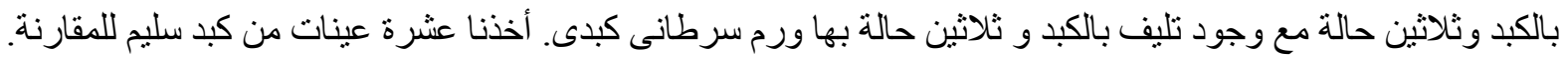

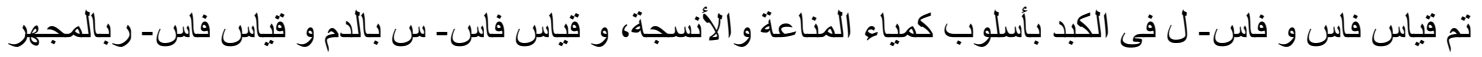
الإلكترونى على خلية الدم البيضاء اللمفية.

النتائج:

وجدت زيادة ملحوظة وصلت إلى مستوى الإعتداد الإحصائى لفاس- س بالدم فى حالات التليف الكبدى و أور ام الكبد

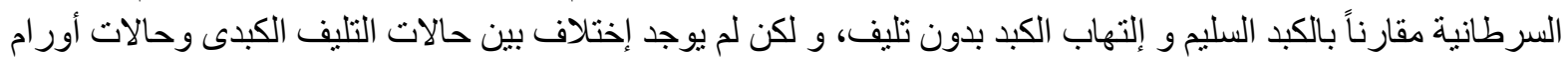

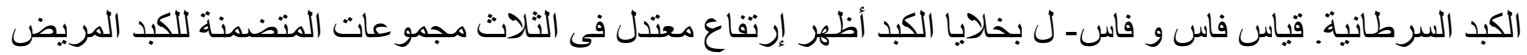

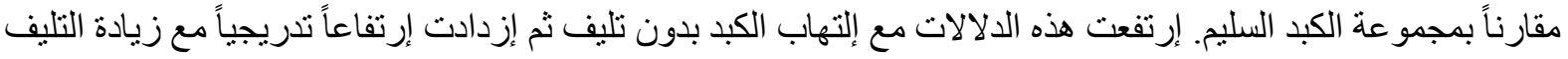

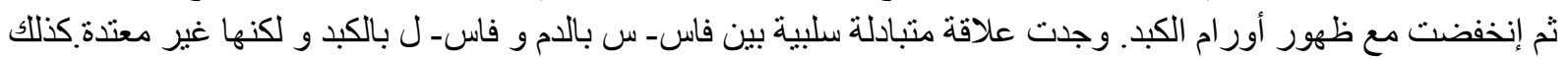
إرتفع فاس- ر بالدم مع زيادة موت خلايا الكبد.

الإستنتتاج:

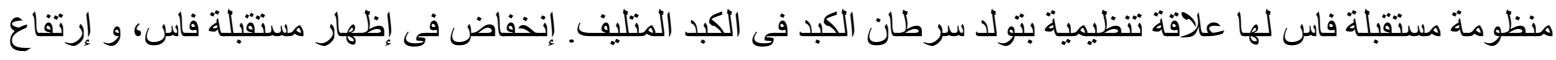

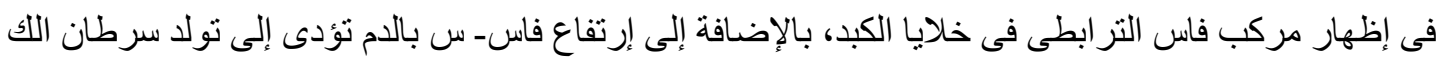


Early Detection of Hepatocellular Carcinoma on top of Liver Cirrhosis.... 